\title{
Towards a sharing economy - Innovating ecologies of business models
}

DOI:

10.1016/j.techfore.2018.06.031

\section{Document Version}

Accepted author manuscript

Link to publication record in Manchester Research Explorer

\section{Citation for published version (APA):}

Boons, F., \& Bocken, N. (2018). Towards a sharing economy - Innovating ecologies of business models.

Technological Forecasting and Social Change. https://doi.org/10.1016/j.techfore.2018.06.031

\section{Published in:}

Technological Forecasting and Social Change

\section{Citing this paper}

Please note that where the full-text provided on Manchester Research Explorer is the Author Accepted Manuscript or Proof version this may differ from the final Published version. If citing, it is advised that you check and use the publisher's definitive version.

\section{General rights}

Copyright and moral rights for the publications made accessible in the Research Explorer are retained by the authors and/or other copyright owners and it is a condition of accessing publications that users recognise and abide by the legal requirements associated with these rights.

\section{Takedown policy}

If you believe that this document breaches copyright please refer to the University of Manchester's Takedown Procedures [http://man.ac.uk/04Y6Bo] or contact uml.scholarlycommunications@manchester.ac.uk providing relevant details, so we can investigate your claim.

\section{OPEN ACCESS}




\title{
TOWARDS A SHARING ECONOMY - INNOVATING ECOLOGIES OF BUSINESS MODELS
}

\author{
Frank Boons and Nancy Bocken
}

Please cite as:

\author{
Frank Boons and Nancy Bocken (2018). Towards a sharing economy - Innovating \\ ecologies of business models, Technological Forecasting and Social Change, ISSN \\ 0040-1625, https://doi.org/10.1016/j.techfore.2018.06.031. \\ (http://www.sciencedirect.com/science/article/pii/S0040162517317808)
}

\begin{abstract}
:
The fragmented academic literature on sharing modes of provision deals with a diversity of initiatives ranging from for-profit business models to commoning initiatives. This literature mainly deals with individual instances, implicitly assuming that the sharing economy comes about by multiplying such initiatives. In this paper we argue that the transition to a sharing economy is a process where sharing and non-sharing modes of provision interact, constituting a complex process of social change. To facilitate research, we provide a literature review of the variegated literature, and develop a conceptualisation of the process of transition to a sharing economy using ecosystem thinking. In addition, we propose an approach to assess the environmental impact of sharing business models that takes the system context into account. This conceptual work is illustrated with the case of personal mobility. This work allows us to define a focused research agenda for researchers interested in the innovation and diffusion of sharing modes of provision as part of the wider transition to a sharing economy.
\end{abstract}




\section{Sharing economy: From isolated initiatives to a systemic perspective}

The sharing economy has gained a strong foothold in the discourse among policy-makers, business managers and academics (Acquier et al., 2017). It comes with explicit normative expectations in terms of employment, social impact and environmental benefits, despite an incomplete understanding of the full impact of the innovative new business models and modes of provision that fall under this label (Martin, 2016, Cohen \& Kietzmann, 2014). ${ }^{\mathrm{i}}$ Sharing initiatives constitute a, potentially disruptive, alternative to existing practices of consumption and production, sometimes challenging the dominant corporate-driven economic model (Wilhelms et al., 2016).

Any particular sharing initiative is not an isolated phenomenon, but instead interacts and co-evolves with other sharing initiatives, as well as with existing non-sharing modes of provision. A first example is the sharing of digitally recorded music through platforms like Napster and Spotify, which has led to a fundamental reshaping of not just the production and consumption of recorded music, but also of the relevance of live performances for artists as a source of income. At the same time, it has opened up new possibilities for independent musicians (Hracs, 2012). A second example is the rise of platforms like AirBnB which facilitate the peer-to-peer sharing of housing. This affects not only the hotel industry, but generates additional tourist streams which affect, in various ways, tourist attractions and large city dynamics (Bock, 2015). A third, non-profit oriented, example is that of independent spaces in cities like Dublin (Bresnihan and Byrne, 2015). Here a community of citizens jointly rents and manages a space which provides a platform for a variety of sharing activities, including cultural experiences and food production.

In each of these examples the emergence and evolution of a particular sharing initiative is connected with the provision of other goods and services. This systemic nature is 
what warrants the label of a 'sharing economy'. However, in much of the current literature this essentially systemic quality of the sharing economy is overlooked. Apart from a tendency to build on isolated examples, the literature is fragmented across disciplines. This inhibits efforts to understand commonalities and differences between initiatives, as well as how such initiatives might interact to evolve into a sharing economy.

We consider this a crucial gap, and propose that to remedy this it is necessary to provide insight into the transition toward a sharing economy. Two lines of inquiry are required: we need to (1) better understand the way in which individual innovative sharing activities scale up and amalgamate into a sharing economy, and (2) provide ways of assessing how such initiatives, in interactions with the wider context, deliver on normative promises in terms of economic, social and environmental outcomes. This article begins to develop these two lines by aiming to provide a conceptualisation and assessment of the sharing economy as a systemic phenomenon, and thus open up a research agenda to understand its dynamics and critically assess its environmental impact, as this currently seems to be the main positive normative driver. We thus seek to answer the following two questions:

\section{How can the transition to a sharing economy be conceptualized using the ecosystem concept?}

\section{How can the environmental impact of that transition be assessed?}

Our argument has three parts. First, we provide systematic insight into the variegated and disconnected literature on sharing business models. We map relevant literature through bibliometric analysis, and assess the normative expectations that are connected to various conceptualizations. This results in an inclusive definition of what we term sharing business models (S-BM). Given the lack of work on the way in which individual business models 
scale up to form a sharing economy, the second part of our argument is to develop a conceptual framework that enables us to investigate the relationships between S-BMs, combining insights from biological ecosystem theory and transition theory (Section 3). This framework includes an approach to assess the environmental impact of business models, answering research question 2 . The constituting elements of the framework are illustrated using the case of personal mobility. The third part of our argument is to develop a research agenda (Section 4). Figure 1 summarizes the structure of our argument.

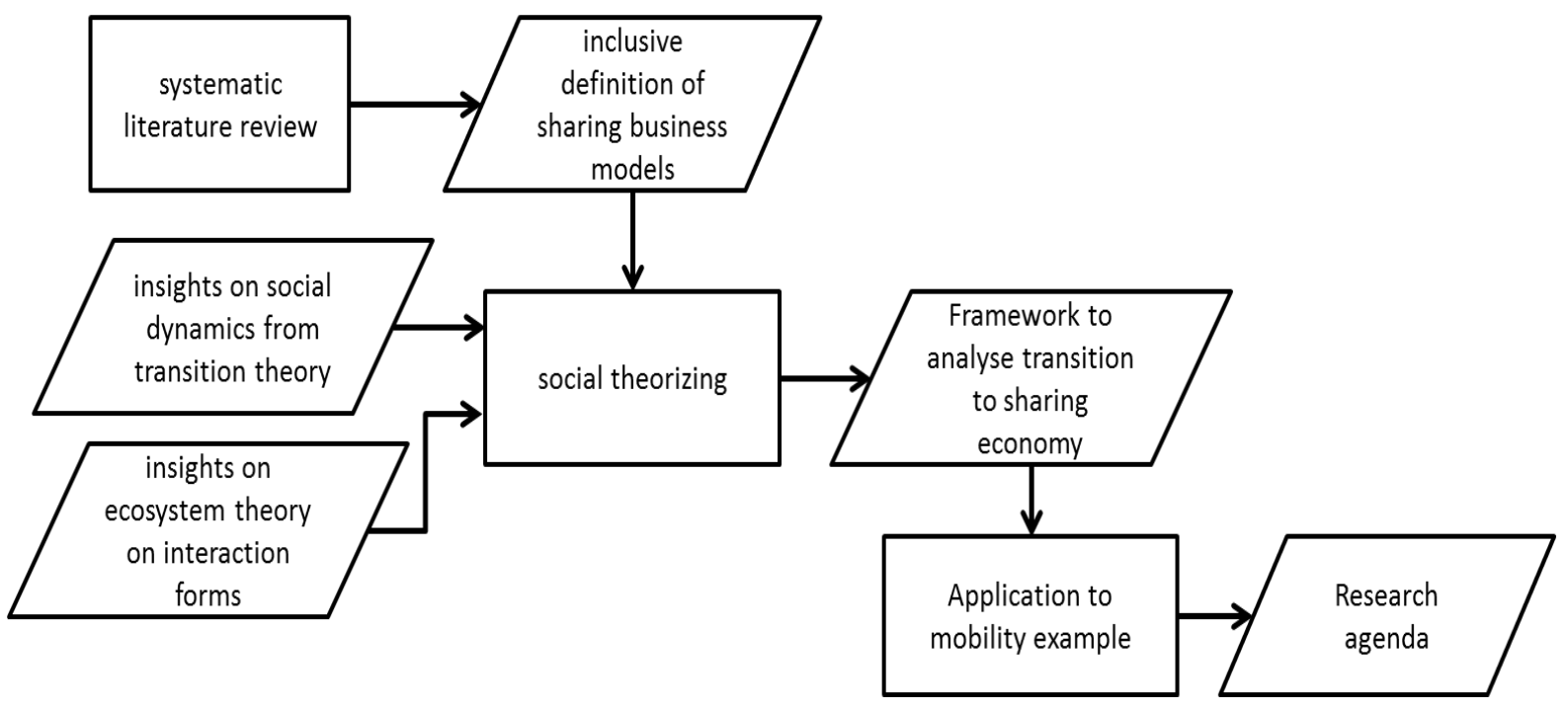

Figure 1. Structure of the article

\section{Literature review}

A rapidly expanding academic literature is covering various innovative forms of sharing: instances where material resources are shared in a way that transforms the social relations among producers and consumers (Belk, 2014; Kennedy, 2015; Schor and Fitzmaurice, 2015; Wittel, 2011). This work is produced by scholars working from a wide array of disciplinary backgrounds, including geographers (Richardson, 2015), economists (Ostrom, 1990), innovation scholars (Acquier et al., 2017), management and business scholars (Bellos et al., 2017), environmental scientists (Tukker, 2015) and sociologists of consumption (Schor and Fitzmaurice, 2015). 
In all this work, a first label used is the sharing economy, which Hamari et al. (2016: 2047) define it as the "peer-to-peer-based activity of obtaining, giving, or sharing the access to goods and services, coordinated through community-based online services". In this definition, online services are central as the distinct way for individuals to coordinate the use of some resource or service.

The phenomenon of commoning lacks this focus on online services underpinning sharing and refers to "acts of mutual support, conflict, negotiation, communication and experimentation that are needed to create systems to manage shared resources", and in that sense has a much broader scope (Bollier and Helfrich, 2014). This literature, which extends the work of Gareth Hardin (1968) and Elinor Ostrom (1990), typically focuses on community-based modes of provision where the emphasis is less on profit-making, and more about the quality of social relations, such community-based local food provisioning. Other labels are collaborative consumption (Botsman and Rogers, 2010) and product-servicesystems (PSS) (Tukker, 2015). The former refers to all forms of peer-to-peer sharing whereas the latter refers to organizing consumption by selling services rather than products, like a laundry service, under the promise that this reduces environmental impact.

These diverse labels all fall under the generic economic sociologist concept of 'modes of provision' (McMeekin and Southerton, 2007; Southerton, 2014) which designates typical ways in which a set of actors interact to combine ideas, material and labour and produce, distribute and consume something of value. We use the term 'business model' (BM) as an overarching label in this article, acknowledging that not all modes of provision have a 'business' background. The term 'sharing economy' denotes an envisioned economy where sharing is the predominant way of organizing the provision for human needs concerning scarce resources. 
Acquier et al. (2017) provide a qualitative description of these diverse literatures on sharing. Here we seek to identify more systematically how sharing as a mode of provision has been addressed in the academic literature. To assess the literature relevant for our purposes, we selected the Scopus database as a resource (Falagas et al., 2008; Vieira and Gomes, 2009). Scopus proves to be more inclusive than Web of Science, which we interpreted as allowing us insight in more recently developing debates. For the same reason, we included conference proceedings into our final set of literature items. This is also relevant to capture work from computer science, where proceedings are important in communicating research findings. In order to scope the diversity of research on this topic we performed a literature review using the following keywords, which together cover the three areas identified by Acquier et al. (2017): "sharing economy”, "collaborative consumption”, “collaborative economy”, “commoning”, “gig economy”, "product service systems”*sharing, "product service systems"*labour. Given the interest in the impact of sharing initiatives on labour relations (mainly in the so-called "access economy") -we tried combinations of keywords such as sharing*labour relations, sharing*employment. These searches resulted in sets of articles that were mostly unrelated to the focus of this article, so we eventually decided to only include the articles found through the search product service system*labour. Table 1 presents the distribution of items we included in our review over these keywords.

In the analysis of these items, our dimensions for assessment were:

(a) definitional variety on S-BM \& distinctive languages

(b) diversity of normative expectations associated with S-BM 


\begin{tabular}{|l|l|}
\hline & $\#$ items \\
\hline "Product service systems" "sharing" & 72 \\
\hline "Product service system" * labor & 9 \\
\hline "Gig economy" & 12 \\
\hline "sharing economy" & 218 \\
\hline "collaborative economy" & 26 \\
\hline "collaborative consumption" & 88 \\
\hline commoning & 78 \\
\hline Total & $503 ; 452$ unique \\
\hline
\end{tabular}

Table 1. Distribution of Scopus-items over 7 keywords used in search

(a) Forms of sharing

From our reading of literature items, and the debate on definitions of sharing in which they engaged, we inferred the relevance of two dimensions: the type of social group in which sharing takes place (intimate, local or public) and the form of compensation (none, token, monetary) (Figure 2). As an important addition, we note the normative value that authors attach to the terms in this typology. 


\begin{tabular}{|c|c|c|c|}
\hline Public & $\begin{array}{l}\text { - Wikipedia } \\
\text { - Movie uploading/ } \\
\text { downloading } \\
\text { - Couchsurfing }\end{array}$ & $\begin{array}{l}\text { - Public } \\
\text { (online) } \\
\text { libraries }\end{array}$ & $\begin{array}{l}\text { - Airbnb } \\
\text { - Zipcar }\end{array}$ \\
\hline \multirow[t]{2}{*}{ Local } & $\begin{array}{l}\text { - Peer-to-peer } \\
\text { product sharing }\end{array}$ & $\begin{array}{l}\text { - Organised } \\
\text { clothing swaps }\end{array}$ & $\begin{array}{l}\text { - Peer-to-peer } \\
\text { rental }\end{array}$ \\
\hline & & & - Launderette \\
\hline \multirow[t]{2}{*}{ Intimate } & $\begin{array}{l}\text { - Car sharing/ } \\
\text { pooling with friends } \\
\text { and family }\end{array}$ & $\begin{array}{l}\text { - Joint baby } \\
\text { sitting } \\
\text { services }\end{array}$ & $\begin{array}{l}\text { - Paid for car } \\
\text { sharing with } \\
\text { friends and family }\end{array}$ \\
\hline & o compensation & $\begin{array}{c}\text { Token } \\
\text { compensation }\end{array}$ & Compensation \\
\hline
\end{tabular}

Figure 2. Different forms of sharing identified

Sharing is defined a social practice where a group of individuals exercises common use and distribution of some object. Originally, this refers to 'intimate' groups like a family or household (Belk, 2010; Price, 1975; Yates, 2016). Such intimate sharing is seen as the origin of positive normative connotations with sharing, leading to more meaningful social relations. Often this type of sharing is not compensated or only marginally compensated (e.g. joint baby sitting services).

This notion of sharing resonates with commoning, which is the collective management and maintenance of some kind of resource (Pór, 2012: 217; cited in Ryan, 2013), associated with social relations that are richer than the disembedded (Polanyi, 1950) market exchanges common to capitalist economies. Thus, commoning is seen as an expression of the social power that is rooted in collective association (Ryan, 2013: 91), and it 
is often connected to the normative aim of creating a more participative, equitable and sustainable society.

The free sharing of information, data or physical spaces (e.g. Couchsurfing, Wikipedia) is a public form of uncompensated sharing. Although Belk (2014) argues that models such as 'wikis', Facebook and Twitter classify as 'pseudo-sharing' because of financing models that are sometimes opaque, we do include the voluntary and free sharing and exchange of data, information and resources (e.g. homes - Couchsurfing) in our summarising figure.

The label 'sharing economy' is distinct from the above as it combines sharing with market transactions: compensated sharing. The sharing economy-label is typically used to refer to the emergence of business models that utilize the Internet as a platform for exchanges in which resources are shared by multiple users (and thus concerns a combination of immaterial and material objects) (Sundararajan, 2016). ${ }^{\text {ii }}$ Schor (2014) rightly notes that to a considerable extent, this debate uses self-definition as a criterion to delineate the sharing economy: if an initiative, or press coverage of it, uses the sharing label, then it is part of the phenomenon. The positive impact of the (assumed) proliferation of sharing business models is contested, in particular due to the negative social implications of the extended diffusion of platform business models, in particular in how these affect labour relations (Davis, 2016). Another label referring to similar empirical phenomena is that of 'collaborative consumption'. Belk (2014: 1597) defines this as “people coordinating the acquisition and distribution of a resource for a fee or other compensation." Defined in this way there is a great overlap with 'sharing economy'; a major difference is that in such compensated sharing coordination is not defined to take place through the Internet.

A distinct literature in environmental science deals with the relative ecological impact of different modes of provision. Based on notions of material efficiency, the concept of 
product-service systems emerged to denote modalities where consumers buy a service rather than a physical product (Tukker, 2015). Thus, it deals with service sharing like the traditional laundrette, which is of interest because it holds a promise of increased material efficiency, and thus less ecological impact than ownership-based modes of provision. Tukker (2015) provides an overview of empirical research assessing this potential, and the difficulties in getting such systems implemented. Launderettes and peer-to-peer rental take place at a local level; whereas Airbnb and Zipcar are examples of globally operating compensated sharing models enabled by the internet and apps. We include these types in our diagram because of the shared use of resources (e.g. cars, power tools). Other forms of sharing (e.g. clothing swaps) associated with reducing one's environmental footprint may take place in an intimate environment (friends, family) or in an organised setting with a token fee for participation.

As indicated by our discussion of definitions, authors make sense of forms of sharing using distinct languages. To map this, we looked at co-citations of literature item key-words. Co-citation occurs when two literature items are cited in the same publication. Journal keywords reflect how an item sits within the 'received' understanding of a topic, while author keywords allow for the inclusion of new terms, which is what we want to find out about in assessing the literature on a new empirical phenomenon. We used Vosviewer, a dedicated bibliometric software program (Van Eck and Waltman, 2010), to transform the data of our complete set of 452 literature items into a network file, which was then analysed using Gephi software. More specifically, we clustered keywords using network component analysis (Blondel et al., 2008). This generated four distinct clusters. 


\begin{tabular}{|l|r|l|r|}
\hline \multicolumn{1}{|c|}{ 1. Political economy of sharing } & \multicolumn{2}{c}{ 2. Engineering sustainable PSS } \\
\hline commons & 17 & product service system & 108 \\
\hline climate change & 15 & sustainable development & 91 \\
\hline conceptual framework & 14 & sustainability & 70 \\
\hline capitalism & 13 & product design & 64 \\
\hline economic theory & 12 & life cycle & 53 \\
\hline neoliberalism & 12 & innovation & 52 \\
\hline theoretical study & 12 & design & 50 \\
\hline commoning & 10 & competition & 44 \\
\hline privatization & 7 & business model & 42 \\
\hline autonomy & 6 & manufacture & 40 \\
\hline & & & 4. Sharing economy \\
\hline human computer interaction & & & 120 \\
\hline employment & 37 & sharing economy & 93 \\
\hline decision making & 32 & economics & 90 \\
\hline research & 26 & collaborative consumption & 73 \\
\hline collaboration & 26 & distributed computer systems & 64 \\
\hline human engineering & 24 & commerce & 51 \\
\hline outsourcing & 24 & internet & 47 \\
\hline industrial economics & 23 & collaborative economy & 46 \\
\hline economic aspect & 22 & information systems & 43 \\
\hline research and development management & 20 & peer to peer & 39 \\
\hline & 18 & economic and social effects & \\
\hline
\end{tabular}

Figure 3. Top 10 keywords of 4 clusters of keywords

Figure 3 summarizes the highest frequency keywords in each cluster (omitting keywords denoting geographical locations). This result confirms that there are distinct languages involved in research on S-BM. CLUSTER 1 is characterized by words we summarize as denoting the political economy of sharing; with 'commoning' and 'commons' among its key terms, it includes economic systems, and socio-economic trends and ideologies ('capitalism', 'neoliberalism', 'privatisation'). Interestingly, items are also often characterized through the keywords 'theoretical study' and 'conceptual framework', indicating the type of research reported on. CLUSTER 2, which we label engineering sustainable product service systems, is distinct in combining 'product service system' and 'sustainability' (as well as ('sustainable development'). Further keywords indicate a focus on designing and engineering. CLUSTER 3 (sharing \& employment) is more difficult to characterize, as it consists mainly of generic keywords. The frequent occurrence of 'employment' is noteworthy, as well as that 
of 'human computer interaction'. CLUSTER 4 centres around sharing economy; here we find keywords referring to (various dimensions of) the economy ('commerce', 'consumption', 'peer to peer'), including 'economic and social effects'.

(b) A systematic overview of normative expectations

A considerable part of the items identified in our literature search communicate normative expectations associated with S-BMs, which are summarized in Table 2. We generally find that expectations relate to the specific clusters identified above. We arrived at the results in Table 2 through manual scanning of the abstracts of the top 25 articles (based on citations). We then tested our findings by automated scanning the abstracts of all 452 items for the identified normative expectations. The typical sources (column 3) were then taken from the top 25 articles.

To sum up, our literature review provides insight into the diversity of S-BM as reported on in academic literature. It shows that this literature is clustered in four distinct groups, each with its own conceptual language and associated normative expectations. 


\begin{tabular}{|c|c|c|c|}
\hline Normative expectation & $\begin{array}{c}\text { Description - } \\
\text { Sharing is expected to: }\end{array}$ & Typical sources & $\begin{array}{l}\text { Associated } \\
\text { to cluster }\end{array}$ \\
\hline Ecological sustainability & $\begin{array}{l}\text { Decrease the ecological impact of } \\
\text { fulfilling needs, compared to } \\
\text { nonsharing modes of provision }\end{array}$ & $\begin{array}{l}\text { Tukker\&Tishner } \\
\text { (2006); }\end{array}$ & PSS \\
\hline Labor conditions & $\begin{array}{l}\text { Decrease labor security and result in } \\
\text { lower compensation for labor provided }\end{array}$ & Davis (2016) & $\begin{array}{l}\text { Sharing } \\
\text { economy; } \\
\text { gig economy }\end{array}$ \\
\hline Customer value & Increase the value delivered by a firm & Hamari (2013) & $\begin{array}{l}\text { PSS; sharing } \\
\text { economy; } \\
\text { collaborative } \\
\text { consumption }\end{array}$ \\
\hline Social relations & $\begin{array}{l}\text { Increase the extent and depth among } \\
\text { users of the same resource, compared } \\
\text { with market based provision }\end{array}$ & $\begin{array}{l}\text { Breshnihan (2015); } \\
\text { Stavrides (2014 }\end{array}$ & Commoning \\
\hline Justice & $\begin{array}{l}\text { Increase just distribution of (access to) } \\
\text { resources and exposition to } \\
\text { environmental harms (i.e. climate } \\
\text { justice) }\end{array}$ & $\begin{array}{l}\text { Esteva (2014); Becker } \\
\text { et al. 2015) }\end{array}$ & Commoning \\
\hline Competitiveness & $\begin{array}{l}\text { Increase the competitive position of a } \\
\text { firm, especially in mature market, } \\
\text { through offering services rather than } \\
\text { products }\end{array}$ & $\begin{array}{l}\text { Tukker\&Tishner } \\
\text { (2006); Mont et al. } \\
\text { 2006) }\end{array}$ & PSS \\
\hline Profitability & $\begin{array}{l}\text { Increases the revenue drawn from } \\
\text { providing services to others }\end{array}$ & Belk (2014) & $\begin{array}{l}\text { Sharing } \\
\text { economy; } \\
\text { collaborative } \\
\text { consumption }\end{array}$ \\
\hline
\end{tabular}

Table 2. Normative expectations as uncovered in the sharing literature

\section{Sharing economy as an ecosystem of S-BMs}

Current literature focuses to a great extent on description, taxonomy and classification as a way to understanding imagined and emerging S-BMs (Cohen \& Munoz, 2016). Additionally, it flags normative implications, which mostly relate to the potential effects of the diffusion of

S-BMs. In doing so, a sharing economy seems to be imagined as a summation of individual S-BMs.

Thus, while the literature provides some understanding of sharing as a conceptual entity, little work has been done on how these individual instances can scale up to form a 
viable economic system (an exception is Mair \& Reischauer, 2016). In this section we therefore extend our findings from the literature review and introduce a more systemic perspective in sustainable business model innovation (Bocken et al., 2014; Boons \& LüdekeFreund, 2013; Stubbs \& Cocklin, 2008).

We develop this more encompassing conceptualization by combining insights from transition theory with a natural ecosystems-metaphor. As Tsujimoto et al. (2015) point out, the ecosystem concept directs attention towards the multiple ways in which a variegated set of actors (or in our case, business models) interact, ranging from competition to mutually supportive connections. It also indicates that the relationship between these interactions and the system-level behavior is not straightforward: individually desirable outcomes can produce unintended system results. In addition, the ecosystem concept calls for a longitudinal analysis of dynamics. We build on transition theory (Geels 2004) to help analyze the longitudinal dynamics of interacting business models. The reason we use transition theory is that at its core are insights about 'dialectic interplay between stasis and change in sociotechnical systems'. This is a necessary addition to insights from ecology, as in social systems we are dealing with reflexive agents who produce different dynamics than agents that mostly lack this capacity (Checkland, 1981).

In biology, an ecosystem refers to a discernible entity that consists of interacting organisms of different species (the community) and their non-living environment, or habitat (Odum and Barrett, 2004). The entity-character derives from the fact that interactions lead to a biotic structure (i.e. such as food webs) and the cycling of materials. The total of interaction between organisms from diverse populations is referred to as community ecology.

Ecosystems are a powerful metaphor for human systems (Boons, 2009; Hawley, 1986). This metaphor has been applied to business communities (Iansiti and Levien, 2004; 
Moore, 1996; Teece, 2007), cities (Boyden et al., 1981; Park, 1911), (regional) industrial systems (Chertow, 2000), and organizations (Aldrich, 1999). There is an affinity between natural ecologies and economic systems, as both can be considered complex adaptive systems (Beinhocker, 2006; Levin, 2007). The linkages between natural and human ecologies have also been explored from this perspective (Boulding, 1966; Foxon et al., 2013).

The ecosystem metaphor has been used in two major ways in the business literature. One defines the business ecosystem as the set of organizations that co-evolves with a focal firm, and whose value creation is dependent on one another (Moore, 1996; Teece, 2010). This interpretation also forms the basis for some of the current work on sharing business models, which looks at platforms and multi-sided markets (Rysman, 2009).

A second interpretation analyses dynamics in communities of organizations. We extend the work of Aldrich (1999) who analyses industries as communities of organizations that interact within a habitat of resources. To begin, we identify the following key elements of an ecology of business models:

1. A community, i.e. a variegated set of (S-)BMs that occupy the same habitat;

2. A habitat, which consists of material, human, cognitive and normative resources necessary for the provision of a socially constructed need. More precisely, the habitat is constituted by two core elements: (1) resource endowments, which includes a pool of knowledge, financial resources, and human resources, as well as material resources and energy, and (2) institutional arrangements, including regulation, industry standards, collective processes for coordination, and legitimation, which together facilitate and shape the flow of resources between economic actors.

The habitat includes the flows of material resources and energy necessary for provisioning. The quantity, speed and quality of these flows affects the eventual ecological impact of any mode of provision (Lifset \& Boons, 2012). The flows and stocks 
of materials and energy also constitute varying availabilities, resulting in competitive relationships among business models.

3. The relationships within the community of S-BMs (see Table 3). There are three basic kinds: competitive (different S-BM compete for limited resources, and success of one implies failure of another), mutualistic (different S-BMs reinforce each other: the success of one enhances the other), and symbiotic (different S-BMs reinforce each other and lead to co-evolution). Note that these are relationships between populations of S-BMs.

'Growth' or 'decline' do not refer to performance of a provisioning agent, but rather to the success of failure of the population of provisioning agents that employ the S-BM. 


\begin{tabular}{|l|l|l|}
\hline & $\begin{array}{l}\text { Relationships between } \\
\text { similar BM (A1 and A2) }\end{array}$ & Nature of relationship \\
\hline Competition & Full competition & $\begin{array}{l}\text { Growth in A1 detracts from } \\
\text { growth in A2 and vice versa }\end{array}$ \\
\hline & Partial competition & $\begin{array}{l}\text { Growth in A1 detracts from } \\
\text { growth in A2 but not vice versa }\end{array}$ \\
\hline & Parasitism & $\begin{array}{l}\text { Growth in A1 leads to decline in } \\
\text { A2 }\end{array}$ \\
\hline & Dominance & A is harmed by presence of B \\
\hline Neutrality & Neutrality & $\begin{array}{l}\text { A controls the resource (incl. } \\
\text { information) flows to A1, A2 and } \\
\text { B, C, D }\end{array}$ \\
\hline Symbiosis/ & Partial mutualism & $\begin{array}{l}\text { A1 and A2 do not affect one } \\
\text { another }\end{array}$ \\
\hline mutualism & & $\begin{array}{l}\text { Growth in A1 stimulates growth } \\
\text { in A2 but not vice versa }\end{array}$ \\
\hline & Full mutualism & $\begin{array}{l}\text { Growth in A1 stimulates growth } \\
\text { in A2 and vice versa }\end{array}$ \\
\hline & Symbiosis & A benefits from presence of B \\
\hline
\end{tabular}

Table 3. Ecological relationships between S-BMs (drawing on Odum 2005; Aldrich 1999)

From individual S-BMs to a sharing economy

We assume the sharing economy to be an ecosystem of S-BMs, which are themselves routinized interactions between the actors that coordinate actions in provisioning for some need. As the literature indicates, there are multiple forms in which provisioning can manifest: ranging from business models in which profit oriented producers seek to market their products and services to consumers; it might also be a community in which members make 
use of some joint resource to provide in their needs. Coordination can be facilitated through digital data technology, but it need not be.

Our first research question requires us to conceptualize how these variegated S-BMs interact with each other, and how they interact with non-sharing forms of provisioning and potentially transition to a sharing economy. This question has received scant attention in the literature (for an exception see Schaltegger et al. (2016). In doing so, we extend the literature on sustainability transitions, which has tended to focus on individual socio-technological systems in analysing the process of change (Boons et al. 2013; Geels, 2002, 2004), and has only recently begun to incorporate insights from on business models (Bolton and Hannon, 2016; Sarasini and Linder, 2017).

The ecosystem metaphor thus allows us to conceptualize relationships between different kinds of (sharing and non-sharing) provisioning, as well as the resources and institutional support they require. As we focus on the transition to a sharing economy, we need to introduce a dynamic element. In biology this has been studied in terms of ecosystem succession, and more recently as an instance of complex adaptive systems dynamics (Levin, 2007; Pickett et al., 2011), where equilibrium states are possible, but not necessary or even likely. Building on this work we interpret the amalgamation of individual sharing forms of provisioning into a sharing economy in terms of co-evolution and positive and negative feedback loops. For a specification of these feedback loops we draw on transition theory, as argued above.

Figure 4 depicts the steps of a transition towards a sharing economy. The figure includes main mechanisms and conditions for each step. 


\begin{tabular}{|c|c|c|}
\hline step & Strategies/mechanisms & conditions \\
\hline (a) Emergence of specific sharing BM & $\begin{array}{l}\text { Joint learning } \\
\text { Experimenting } \\
\text { Designing } \\
\text { Strategic niche management }\end{array}$ & $\begin{array}{l}\text {-Availability of resources } \\
\text {-Possibility for mutualistic } \\
\text { connection to other BMs } \\
\text {-Absence of competition for } \\
\text { available resources }\end{array}$ \\
\hline $\begin{array}{l}\text { (b) Increased occurrence of specific } \\
\text { sharing BM }\end{array}$ & $\begin{array}{l}\text { Enrollment through marketing } \\
\text { Enrollment through imitation }\end{array}$ & $\begin{array}{l}\text {-potential user base and resource } \\
\text { availability } \\
\text {-absence of hype cycles }\end{array}$ \\
\hline (c) Widening scope of sharing BMs & $\begin{array}{l}\text { General promotion } \\
\text { generalist BMs that are mutualistic } \\
\text { with sharing BMs } \\
\text { increasing returns } \\
\text { imitation } \\
\text { adoption by incumbents }\end{array}$ & $\begin{array}{l}\text {-availability of supporting } \\
\text { technological infrastructure }\end{array}$ \\
\hline $\begin{array}{l}\text { (d) Breaking down dominance of non- } \\
\text { sharing BMs }\end{array}$ & $\begin{array}{l}\text {-succesful shaping of infrastructure } \\
\text { through political strategies } \\
\text {-replacement of parasitic } \\
\text { relationships with non-sharing BMs } \\
\text {-pressure on keystone BMs }\end{array}$ & $\begin{array}{l}\text { Lack of adaptive capacity of } \\
\text { incumbents }\end{array}$ \\
\hline $\begin{array}{l}\text { (e) Change of habitat and input-output } \\
\text { to system-environment }\end{array}$ & & \\
\hline
\end{tabular}

Figure 4. Steps depicting the amalgamation of individual S-BM into a sharing economy, with main mechanisms and conditions

We discuss each of these in turn, drawing on what is available in the literature reviewed above, the general conceptual literature on business models, and insights from socio-technical transitions. For each step, we add illustrative insights from the case of personal mobility. ${ }^{\text {iii }}$ In the past decade, personal mobility has been subject to substantial innovation in terms of new S-BMs. At least some of these explicitly seek to address the substantial ecological impacts associated with personal mobility. As our framework outlines a process of change, we begin by specifying features of the baseline situation. The reason we are using this case rather than empirical cases from our literature review is that this literature does not provide us with empirical or conceptual insight into the dynamics between business models. 
In industrialised countries, the provisioning of personal mobility is accomplished through a combination of BMs based in a variety of technologies including motorized vehicles and bicycles. Some of these are based in personal ownership of vehicles (bikes, cars, animals), while in other BMs ownership (and the associated infrastructure) is shared (S-BMs). The latter include public transportation systems, being highly formalized and extended forms of commoning. Other S-BMs have an established position; these include carpooling, taxis, car rental and leasing. Finally, within households there is to some extent intimate sharing of vehicles. Together with nonvehicle forms of mobility, this constitutes the community of BMs that provides our baseline situation.

\section{(a) Emergence of new varieties of sharing modes of provision}

Empirical research on business models suggests these are not a constructable 'thing', but instead are constituted through recurring (strategic) interactions among the actors involved in various acts of provisioning (i.e. suppliers, producers, and consumers), leading to learning, the build up of joint expectations, and the establishment of stable connections between involved actors (Roome and Louche, 2016; Sosna et al., 2010). Business model innovation (for sustainability) is a constant process of iteration and experimentation (Chesbrough, 2010) and often multiple business models coexist even within one firm (Weissbrod and Bocken, 2017). This resonates with the notion of experimenting in research on commoning (Bresnihan and Byrne, 2015; Engeström et al., 2016). The building up of joint expectations signals that at this stage actors may draw on specific normative expectations to involve others and acquire necessary resources.

In the transition literature, the concept of 'technological niche' is used to indicate that this process requires a favourable context (Smith, 2016; Kemp, Schot, \& Hoogma, 1998); in ecological terms this context translates into a habitat which provides the necessary resources, 
and the availability of actors with which mutualistic relationships can be developed. Sharing may also be induced through limited availability of actors, as in the case of product service systems, which is to some extent related to increased price competition in markets (as a result of scarcity of demand), leading firms to look for value-added strategies through service provision (see for instance Yoon, Kim, \& Rhee, 2012).

In terms of ecological relationships, the emergence of new S-BM enriches the ecology when it provides new goods and services. In this case it may still draw on resources and infrastructure that are also used by existing initiatives and business models, thus creating a competitive relationship, for instance around the space needed to stall unused vehicles, and the roads they are driven on. Alternatively, mutualistic relationships may result, when a sharing initiative strengthens others (and vice versa). When a new sharing initiative overlaps with existing ones in terms of providing in similar needs, competition occurs: the resource over which initiatives compete being user demand.

The past decade has shown several innovative business models for personal mobility, most significantly car-sharing initiatives (Shaheen and Cohen, 2013) and bike sharing schemes in cities (Drake et al., 2013). These constitute innovations, even as organized carsharing has a history going back to the early 1940s. In the 1990s, technological development around reservation and accounting systems as well as on-board computers allowed such systems to grow. Recent forms of car-sharing differ substantially from earlier SBMs, being based in wireless communication that allows real time vehicle tracking and user interaction. As such, these new BMs require substantial experimentation and learning, much of which revolves around configuring the organization of sharing in relation to the local habitat , including availability of parking spaces and congestion patterns (Millard-Ball et al., 2005). Vehicle technology is sometimes part of that experimentation, involving electric cars. 
In addition to new entrepreneurial market entrants, incumbent firms such as car manufacturers and rental firms develop new S-BMs alongside their existing businesses (Schaltegger et al., 2016); this is expected to be a requirement for future competitiveness (Hanley et al., 2013), which is a first indication about new variety being shaped by resource availability (in this case, consumer demand).

Another innovative S-BM, on demand ride services (EEA, 2016), uses web-based information exchange to allow individual car owners to perform a service similarly to taxis, thus providing an instantiation of the gig economy. The platform Uber is a primary case of this particular variety with a globally extended network (Rauch and Schleicher, 2015).

Another evolving variety of S-BM is bike-sharing. Like car-sharing, it has existed for decades, but it gained new popularity in the last 5-10 years (Fishman et al., 2013; Parkes et al., 2013). Current initiatives offer new features through the use of GPS, which enables tracking bikes, allowing for innovative pricing structures that increase attractiveness to consumers. Different varieties exist, from traditional bike-rental services to experiments with bikes that are dispersed throughout city centres, such as Mobike. The latter again involves substantial experimentation: whereas in China this model is successful, in Western countries adaptations to local practices and notions of sharing are required (Lan et al., 2017).

In the Netherlands, major initiatives for bike and car sharing have been actively developed by the main supplier of national public transport (Turnheim and Håkansson, 2015). Here the mutualist relationship between public transport (itself a long standing S-BM) and new forms of sharing are exploited. 
(b) Self-reinforcing feedback loops that increase occurrence of a particular sharing mode of provision (enrolment)

The second step concerns the scaling up of specific instances of S-BM. Here we are interested in dynamics of enrolment (Callon and Law, 1982): how do certain instances of sharing become popular, or even the preferred way of provisioning for a certain need? This topic is treated differently in the literatures on which we draw: in business-oriented work scaling up seems to be implicitly considered as desirable as indicated by a focus on generating growth. For instance, the number of customers for a product or service and markets served are increased to accumulate profits (Ansoff, 1957). In research on social businesses, it is about scaling the positive social or environmental impact of the business (e.g., contributing to health, education, sanitation) for an increasing number of customers (Bocken et al., 2016). Work oriented towards collaborative consumption and commoning indicates that enrolment needs to adhere to specific limits, beyond which the quality of social relations becomes difficult to achieve (Poteete and Ostrom, 2004). Such cases are in essence localized, and diffusion takes place through creating similar commoning networks in other local contexts (see (c)).

If local embeddedness is not inherently part of the S-BM then diffusion is a matter of enrolling users and providers of resources to grow the scale of the initiative. There is substantial work from marketing that sheds light on specific characteristics to be considered in relation to consumer acceptance of business models (Möhlmann, 2015; Rexfelt \& Hiort af Ornäs, 2009), as well as innovative ways of enrolling, such as through gamification (Hamari, 2013). More generally, the scaling up of sustainable business model has been conceptualized as a process of co-evolution (Schaltegger et al., 2016).

The business model may have qualities that create increasing returns to adoption (Arthur, 1989). Sharing platforms have that quality, as their usefulness increases with the 
number of participants. This self-reinforcing dynamic is limited by habitat limitations of resource availability and infrastructure capacity.

Another dynamic is that of imitation, which can occur in societal fields engaged in the provision for specific needs (DiMaggio and Powell, 1983). This dynamic has also been observed in relation to business models (Casadesus-Masanell \& Zhu, 2013; Schaltegger et al., 2016).

One possible self-reinforcing feedback loop which has substantial consequences for the ecological sustainability is the emergence of rebound effects (Binswanger, 2001; Hertwich, 2005). Changing towards a sharing mode of provision may lead users to increase their level of use because they perceive it to be less costly (Druckman and Jackson, 2009). This may eliminate, or even reverse, the potential ecological impact reduction.

The concept of a technological niche as earlier defined can be enriched by the way it was originally used in ecology, as this enables an understanding of the extent to which a specific instance of sharing can grow (Popielarz and Neal, 2007). The question is to what extent the habitat provides the necessary resources and what the level of competition is across those. This requires an assessment specific for each case within its relevant habitat. Dampening feedback loops may occur through the limited availability of generic resources necessary for sharing (time, Wi-Fi- networks for mobile communication, physical space for storing non-used shared objects such as cars). However, resource scarcity may also induce actors to engage in sharing (Belk, 2014).

A final issue concerns the persistence of enrolment. In relation to technological niches, hype-cycles have been observed (Verbong et al., 2008). It is likely that sharing modes of provision are prone to such cycles, although empirical studies are not yet available.

In relation to personal mobility it must be noted that there is little empirical insight into processes of enrolment. What is available are quantitative data for various new BMs. For 
instance, regarding cars we can assess occupancy levels of vehicles. In the UK, the average number of people using one car has been stable between $2002-2015$ at $1.5 ;{ }^{\text {iv }}$ in the Netherlands that number is lower (CBS, 2016). There are thus much 'free' seats in existing cars, providing a potential for enrolment into S-BMs. Likewise, data on the enrolment of users into various S-BMs confirm its diffusion. Figure 4 shows participation in car-sharing in the EU.

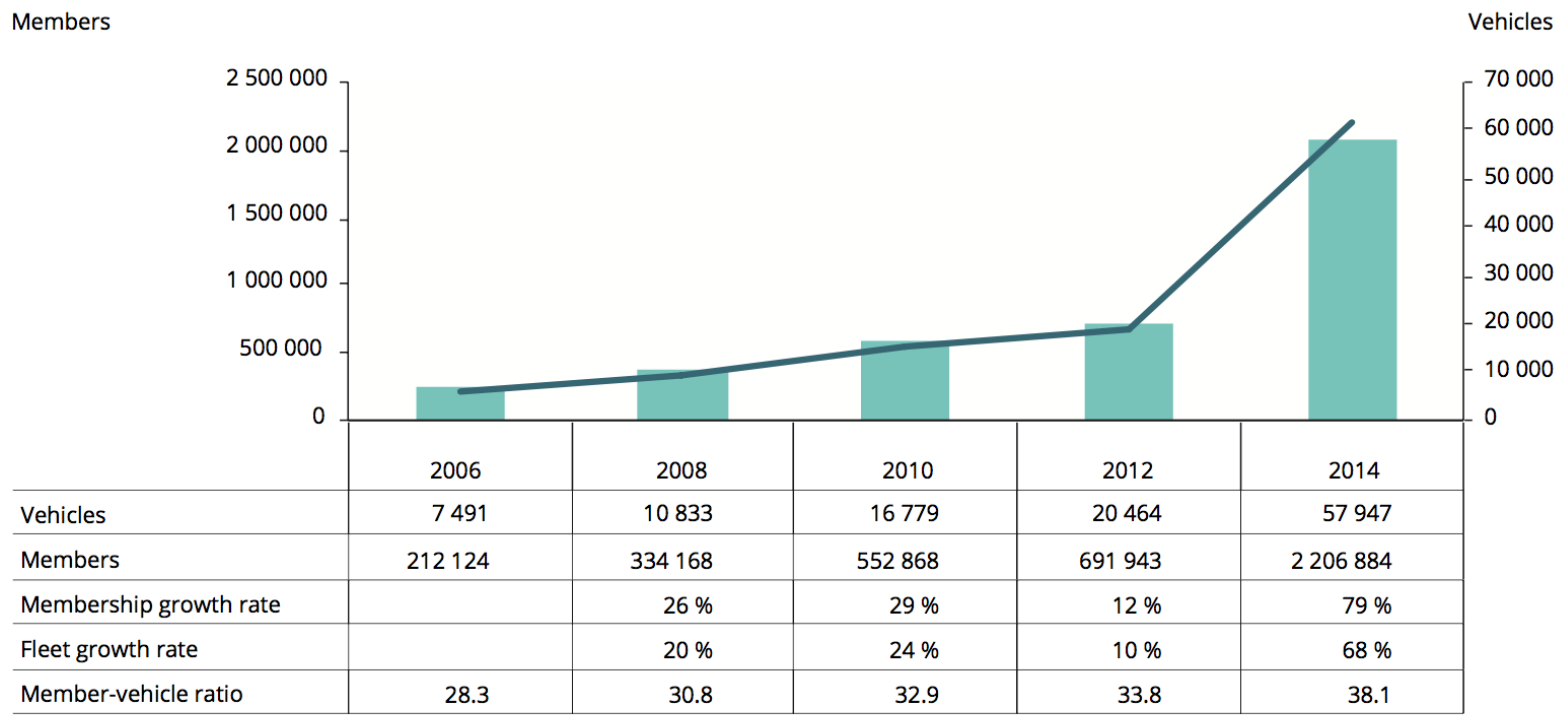

Members Vehicles

Figure 5. Rise in European car sharing 2006-2014( EEA, 2016)

Similarly, 'on demand ride services' (EEA, 2016) are quickly growing globally, interestingly competing with a similar BM, i.e. traditional taxi usage. ${ }^{\vee}$ Despite this successful enrolment, car-sharing remains a "niche product". In 2010, the percentage of the UK population participating in car clubs was under $0.2 \%$ whereas the UK was neither a first mover nor a laggard. Likewise, an international comparison reveals that enrolment of bike-sharing is modest in absolute numbers in both countries.

(c) positive feedback loops that increase occurrence of more varieties (widening scope) 
In the third step, we assess how sharing modes of provision in general can increase in occurrence. We can distinguish mechanisms related to habitat (resources and infrastructure) and interaction with other business models.

A dominant strand in the sharing literature is how the technological infrastructure of the internet, in connection with mobile devices, has provided an inductive infrastructure for sharing modes of provision (Gansky, 2010). Some even argue that this infrastructure provides consumer protection (Koopman et al., 2015). The infrastructure for the (wireless) exchange of digital data (internet) is key to many of the sharing initiatives discussed in the literature. Its business model combines public provision of infrastructure, the use of which is coordinated through a system of providers. Much of the content, which is communicated, is provided through business models where a service is exchanged for access to user data, or exposure to advertisements.

A further element in the infrastructure that plays the role of a generalist species are smart phones and other mobile devices, that enable individuals to communicate (Gansky, 2010). Again, there are specific business models associated with the provision of mobile phones; relevant characteristics are (1) the combined sales of Internet access and the smartphone itself, and (2) the use of apps to extend the functionality of the smartphone. As the technical requirements (in terms of processor capabilities, screen resolution and functionality) for apps tend to increase over time, both (1) and (2) lead to a relatively short life cycle of smart phones (for insight into the carbon footprint of the infrastructure, see Fehske et al., 2011; Paiano et al, 2013). One mechanism here is the emergence of generalist species (Liwarska-Bizukojc et al., 2009) that facilitate sharing modes of provision.

Considering the provision of personal mobility, we find limited explicit evidence for imitation across new S-BMs. Yet it seems likely that to some extent these are part of a generic 'wave', and perhaps hype, of sharing initiatives for which the substantial number of 
popular publications about S-BMs is indicative. Schaltegger et al. (2016) describe a clear process of replication by an incumbent, Daimler, which developed Car2Go together with the car rental company Europcar in 2009 once the market for car-sharing became more established. Outside the UK and The Netherlands, another example is the emergence of a second demand ride service Lyft, which quite explicitly positions itself as a direct competitor to the current market leader, Uber.

We do have insight in mechanisms that act as positive feedback loops. First of all, the new variety reported under step (a) typically utilizes wireless communication. Thus, the associated infrastructure and devices (and associated business models) has a mutualistic relationship with these S-BM. This technology resembles so-called generalist species in ecosystems: they can fruitfully figure in the provision of a large number of human needs (Gansky, 2010).

The growth of wireless communication facilitates new forms of sharing, while the popularity of these new forms further entrenches such devices into the everyday life of people, thus creating a positive feedback-loop, which is further enhanced by mobile apps for planning trips (EEA 2016, 62).

Another mechanism is modular expansion. Stadtauto Berlin in Germany developed a station-based carsharing business model (now named "Greenwheels") that can be easily replicated at many locations (Schaltegger et al., 2016). It aims to be compatible with public transport and promotes sustainability on its website greenwheels.com. Greenwheels launched in the Netherlands in 1995 and currently is the biggest car-sharing provider there, providing discounts for national railway (NS) season ticket holders.

(d) breaking down of negative feedback loops and keystone BMs holding the existing (nonsharing) system in place 
In addition to considering the mechanisms that facilitate enrolment and widening scope of sharing modes of provisioning it is important to consider that these dynamics take place in an existing economy. As a consequence, the interaction of new business models and initiatives with existing ones potentially affects enrolment and scope widening.

Transition scholars have used the notion of a socio-technical regime to capture the constellation of incumbent firms, technologies, and accompanying institutional frameworks, and its in-built mechanisms serving to perpetuate the status quo (Geels, 2004; Geels, Tyfield, \& Urry, 2014). From an ecology perspective, this notion is useful as long as the regime is conceptualized as the on-going set of interactions among actors, rather than as a fixed entity with explanatory power. Specific pathways have been identified through which sociotechnical regimes can change (Geels \& Schot, 2007; Smith, Stirling, \& Berkhout, 2005). These need to be fleshed out with specific ways in which actors interact. One example is the way in which both incumbent actors and those proposing new business models engage in framing to (de-)legitimize the other (Geels \& Verhees, 2011; Martin, 2016). In addition to framing, actors typically engage in political strategizing to ensure access to resources, legitimacy and access to jurisdictions to advance their position towards existing business models; this is currently happening in relation to sharing (Rauch and Schleicher, 2015).

We enrich the notion of a socio-technical regime with the ecological concept of keystone species (Cottee-Jones and Whittaker, 2012; Mills et al., 1993). Definitions vary, but the common element is that they identify species whose removal from the ecology would lead to the collapse of its structure (Iansiti and Levien, 2004). This can be through its dominant influence in interaction with other species, but also through it being a provider of crucial infrastructure. This notion can be used to define the structure of the regime in a way that indicates where leverage points exist for changing it. 
It should be noted that part of the sharing literature does not engage with the notion of changing existing modes of provision; instead it seeks to develop 'insulated' alternative spaces. This is an important omission when the possibility of parasitic relationships is considered. If a S-BM has a parasitic or mutualist relationship with a non-sharing business model then it will be unlikely to lead to breaking down of the existing system. Consider car sharing models using petrol fuelled cars; these support the non-sharing business model of fossil fuels. Including such possibilities in the analysis is a key added value of the conceptualization proposed here.

The European mobility system, like in most industrialised countries (Urry, 2004), consists of a dominant car-regime, which in most European countries accounts for $85-90 \%$ of inland passenger kilometers, and subaltern train, tram, bus, cycling regimes. In countries like the UK alternatives to the automobility regime remain marginal. Rail passenger miles have increased $51 \%$ since 2001 , but still accounted for only around just over $8 \%$ of 'total inland passenger km' in 2012. Cycling declined from 33\% of all vehicle miles travelled in 1949 and only $1 \%$ by 2009 in the UK (Hodson et al., 2015). Thus, the potential for S-BM utilizing cars is considerable: the passenger kilometres could potentially be provided with a smaller number of cars. At the same time, such a shift would imply that S-BMs support the existing carregime centered around multinational OEMs, which have yet to show their ability to transform to low/zero carbon vehicles (Hodson et al. 2015). The situation is similar in the Netherlands: while experimentation with low-carbon mobility is occurring, there remains a deeply ingrained habit of supporting automobility in policy (Turnheim et al., 2016). At the same time, both countries differ in their appetite for carsharing. In the UK the momentum appears limited (Hodson et al. 2015) while in the Netherlands car-sharing (along with the emergence of electric vehicles) is viewed much more positively (Turnheim et al., 2016). 
Globally, carmakers respond to the emergence of S-BMs, as well as a light increase in zerocar households as reported by the American Association of State Highway and Transportation Officials 2013 Commuting in America, 2013). Daimler owns Car2Go, which rents out small cars in a flexible model like Zipcar, whereas BMW has backed DriveNow. ${ }^{\mathrm{vi}}$ As a result, some of the largest car-sharing businesses are now owned by incumbent firms, taking up a big part of the market share of S-BMs (Shaheen and Cohen, 2013). ${ }^{\text {vii }}$

In all, if we consider OEMs and their associated BM (individual ownership of vehicles) as a keystone species in the ecology, these activities show an ability to adapt. Carsharing likely maintains or even expands car dependency, and as such car sharing might simply be a different way to extend the life cycle of the industry. Dargay et al. (2007) for instance project that the global vehicle stock will be 2.5 times greater in 2030 than in 2002 and new car registrations globally are on the rise.

The situation for Uber is substantially different, as incumbents have mobilised their political capital to seek legislative protection against this S-BM. The lower prices are argued to come from avoiding taxes or squeezing margins through flexible work contracts which again leads to opposition from incumbents and legislators for unfair advantage. viii Furthermore, the trend of autonomous cars, backed by incumbents such as Daimiler, GM and Ford, but also Uber and Tesla and further companies such Google and Tesla, is likely to give a further boost to sustaining car reliance. ${ }^{\text {ix }}$

For these S-BM to take hold, urban (re)development and (re)planning and investments in new infrastructure will be necessary, as the IPCC notes, in envisioning carbon neutral mobility systems (Sims et al., 2014). For S-BMs utilizing cars as well as bikes, local authorities are seen to have an essential role, as is clear from the UK and Netherlands evidence.

Companies such as Tesla (electric cars), and the niche start-up Riversimple in the UK (hydrogen fuel cell cars) contribute to redevelopment of the existing infrastructures. 
Riversimple is an interesting emerging hydrogen fuel cell car company that employs a S-BM (users pay a monthly all-inclusive fee) that is embedded in sustainable technology and a comprehensive service offering (Wells, 2016; Bocken and Short, 2016). Its target is to go into production towards the end of 2018 and gradually roll out its business across the UK town by town, in tandem with hydrogen refilling stations (Riversimple, 2016). Here a S-BM is used as a way to introduce radically new technology into the market. Tesla is building its supercharger network - allowing customers to charge their cars within minutes - to enable long-distance travelling with electric cars, helping to increase its adoption and reach. ${ }^{\mathrm{x}}$ Customers receive $400 \mathrm{kWh}(\sim 1,000$ miles $)$ for free and pay a fee for higher usage; properties (e.g. restaurants, hotels) receive the first two Tesla wall connectors free of charge when installed in visible / convenient locations.

(e) change of the habitat and/or input-output to system environment as a result of these. As a result of steps (a)-(d) the habitat of the ecosystem will be modified, as resources become depleted, and institutional infrastructure is created that in turn facilitates (or impedes) new variety and conditions for enrolment, scope-widening and breaking down keystone species. In addition, the evolving community will have a differential impact on the system environment, i.e. the wider social-ecological system in which it resides. An assessment of this impact requires the delineation of a system boundary. Crucial difference with other conceptualizations is that for environmental impacts an integrated assessment is required of the community of sharing and non-sharing BMs as a whole, similar to assessments of urban metabolism (Timmerman \& White, 1997; Villarroel et al., 2014). Cohen and Munoz (2016) indicate the rich variety of S-BM that can be found within the city boundary. Shaheen et al., (2009) take the national market as their system demarcation. This necessitates a focus on 
particular S-BMs, making the application of an ecological perspective more conceptual than empirical.

For the social environment, it is interesting how the concept of commoning resonates with autonomy (Esteves, 2016). This suggests a separation of the initiative from other parts of the community of BMs, or the creation of a self-sufficient community. In its juxtaposition to neoliberal, capitalist economies it also clearly is intended as an alternative to currently dominant modes of provision in most Western societies.

In this article, we focus on environmental impact, i.e. the way in which an ecology of BMs interacts with its biophysical environment. This means that for any S-BM to contribute to environmental sustainability, it needs to decrease the level of environmental impact of the system as a whole. This approach differs from assessments that have been made up till now, which tend to isolate specific aspects and take these as evidence for improved environmental performance. Examples include pre-empted car purchase as a result of carsharing (Firnkorn and Müller, 2011; Nijland and van Meerkerk, 2017) and carsharing having more average persons per car than privately owned cars (Frenken, 2017).

Defined as a change from an existing level of impact, the quantified impact from a systemic perspective can be expressed as:

Differential impact of $\mathrm{S}-\mathrm{BM}=\mathrm{dI}+\mathrm{iI}+\mathrm{S}-\mathrm{R}$

$\mathrm{dI}=$ direct resource use $\mathrm{S}-\mathrm{BM}$

iI = indirect impacts, generated through consumption-related rebound effects

$\mathrm{S}=$ increased resource use induced in symbiotic and mutualistic BM

$\mathrm{R}=$ reduced resource use induced in competing and parasitic BM 
The contribution of S-BM to reducing environmental impact is often framed in terms of 'increased utilization of resources'. This equation indicates a slightly more complicated effect. First, unless a S-BM uses resources already available in the system (as for example carpooling does), it comes with additional material and energy use (dI): new cars and bikes are introduced into the system. Second, S-BM may have rebound effects (Druckman et al., 2012), whenever the associated behavioural change and cost savings lead to additional consumption (iI). For platform-based S-BM, this includes any additional consumption that results from the marketing which is generated through the private data collected and sold to other firms. A further impact is generated when an S-BM has a mutualistic or symbiotic relationship with other BMs (S). Finally, an S-BM may reduce the provision of needs through competing and parasitic BM $(\mathbf{R})$, reducing the overall environmental impact.

To make actual assessments, a system boundary needs to be defined; in addition, the timescale for impacts needs to be made explicit. The first problem has been addressed in relation to LCAs, where a 'functional unit' is used in combination with decision-making rules about what impacts to incorporate (ISO, 2006). For our purposes, a boundary needs to be drawn around an ecology of BMs, and consequently continuity of habitat is a major criterion. As a result, regional or even local ecologies can be delineated as unit of analysis(Kennedy et al., 2007) . The timescale is relevant as the positive impact of S-BM may occur only over a longer time period.

In personal mobility, many S-BM that have been introduced for personal mobility will lead to reduced environmental impact only after several years; initially, they involve the introduction of additional materials (in the form of new cars, bikes, and electronic devices used to to facilitate their monitoring and sharing) into the ecosystem (dI). Table 4 presents indicative examples. 


\begin{tabular}{|c|c|c|c|}
\hline & & Examples in personal mobility & $\begin{array}{c}\text { Consequences for environmental } \\
\text { impact }\end{array}$ \\
\hline \multirow{4}{*}{$\begin{array}{c}\text { Increased resource } \\
\text { use in mutualistic and } \\
\text { symbiotic (S-)BMs (S) }\end{array}$} & \multirow{2}{*}{$\begin{array}{l}\text { S-BM reinforces other } \mathrm{S} \text { - } \\
\text { BM }\end{array}$} & $\begin{array}{l}\text { Last-mile bikesharing supports public transport (Kahn } \\
\text { Ribeiro et al., 2007) }\end{array}$ & \multirow{2}{*}{$\begin{array}{l}\text { Reduced overall impact if the } \\
\text { combination of walking-cycling-public } \\
\text { transport replaces car use }\end{array}$} \\
\hline & & $\begin{array}{l}\text { Bicycle and public transport infrastructure encourages } \\
\text { walking in cities (Kahn Ribeiro et al., } 2007\end{array}$ & \\
\hline & \multirow{2}{*}{$\mathrm{S}-\mathrm{BM}$ reinforces $\mathrm{BM}$} & $\begin{array}{l}\text { Carsharing with electric fleet supports renewable } \\
\text { energy (Kahlen \& Ketter 2015) }\end{array}$ & $\begin{array}{l}\text { Long term reduction of impact due to } \\
\text { shift to renewable energy (but initial } \\
\text { rise due to additional materials } \\
\text { introduced) }\end{array}$ \\
\hline & & Sharing through platforms reinforces smartphone use & $\begin{array}{l}\text { Increased impact, depending on the } \\
\text { replacement cycle of mobile phones }\end{array}$ \\
\hline \multirow{7}{*}{$\begin{array}{c}\text { Decreased resource } \\
\text { use in competing and } \\
\text { parasitic }(\mathrm{S}-) \text { BMs }(\mathbf{R})\end{array}$} & \multirow{3}{*}{$\mathrm{S}-\mathrm{BM}$ replaces other $\mathrm{S}-\mathrm{BM}$} & $\begin{array}{l}\text { Bikesharing replaces public transport Fishman (2013, } \\
\text { 2016) }\end{array}$ & Reduced environmental impact \\
\hline & & $\begin{array}{l}\text { Taxi services like Uber and Lyft decreases public } \\
\text { transport use }\end{array}$ & $\begin{array}{l}\text { Increased impact assuming same miles } \\
\text { travelled }\end{array}$ \\
\hline & & carsharing services replace carpooling & Reduced impact \\
\hline & \multirow{4}{*}{ S-BM replaces BM } & Carsharing replaces self-owned car & $\begin{array}{l}\text { Additional material resources and } \\
\text { embodied emissions are introduced into } \\
\text { the system; potential for rebound effect } \\
\text { increases }\end{array}$ \\
\hline & & $\begin{array}{l}\text { Telecommuting practices (shared workspaces) and car } \\
\text { free days replace driving (Kahn Ribeiro et al., 2007) }\end{array}$ & $\begin{array}{l}\text { Overall change in impact depends on } \\
\text { contribution of shared workspaces }\end{array}$ \\
\hline & & *Bikesharing replaces walking or self-owned bicycle & $\begin{array}{l}\text { Additional material resources and } \\
\text { embodied emissions are introduced into } \\
\text { the system; potential for rebound effect } \\
\text { increases }\end{array}$ \\
\hline & & $\begin{array}{l}\text { *Carsharing pre-empts car purchase (Firnkorn \& } \\
\text { Müller 2011) }\end{array}$ & $\begin{array}{l}\text { long term prevention of material } \\
\text { resources and embodied emissions }\end{array}$ \\
\hline
\end{tabular}


In addition to this quantitative assessment of ecological impact, the ecosystem perspective suggests a qualitative assessment, in two ways:

- increased entrenchment of unsustainable BMs: through its success, a S-BM may strengthen the position of unsustainable BMs with which it has mutualistic or symbiotic relationships. An example of this would be the way in which many sharing BMs use mobile phones as a device for coordinating the sharing;

- increased fragility of sustainable BMs: through its success a S-BM may negatively affect sustainable BMs with which it competes or on which it is parasitic. The way in which bike sharing might compete with public transport might be an example.

This qualitative assessment complements the view adopted in many studies of sustainability transitions, where the unsustainable regime resists the diffusion of more sustainable niches. Put in those terms, increased entrenchment highlights the possibility that a successful niche may strengthen parts of the regime, and increased fragility highlights that niches compete with each other, also across different socio-technical systems.

\section{Conclusions}

Our inclusive review of the academic literature on sharing business models reveals distinctive languages for conceptualizing this phenomenon. In addition, we uncovered a variety of normative expectations associated with S-BM. Although these expectations often refer to desired macro states (socially and environmentally sustainable economies), there is little insight into the mechanisms through which such desired states could be achieved. Our specification of these mechanisms (see Figure 3) provides a novel conceptual language to study this phenomenon. In addition, it supports a more systemic assessment of the environmental impact S-BMs. We have illustrated this perspective with empirical material on the provision of mobility in the Netherlands and the UK, which indicates the value added. To 
the extent that data are available, it shows that an understanding the emergence, diffusion and impact of S-BMs, requires us to look at the competitive and mutualistic relations with other business models, as well as with the ecosystem habitat. We find mutualistic relationships between various forms of S-BM (like public transport with bike and car sharing in the Netherlands), but also between sharing and more generic services such as the provision for wireless communication. The case also illustrates the complexity of assessing how S-BM deliver on normative expectations, in particular the reduction of environmental impact. In part, this is due to rebound effects; in part, it results from emerging S-BMs using new cars and bikes, thus expanding the resource base rather than delivering on the promise of increased use of existing resources.

The case illustration provides support for research that builds from the start on the perspective of innovation in ecologies of business models. This research connects research in sustainability transitions with that on business model innovation, which up to date lacks a systemic theoretical orientation (Foss and Saebi, 2017).

There are two main reasons for extending research into the sharing economy. First, as an empirical phenomenon, S-BM seem to be diffusing rapidly, and it is important to understand how, and to what extent this diffusion will lead to a qualitative change in our economies. Secondly, to the extent that normative expectations form a basis for stimulating the diffusion of S-BM, there is a need to see how this can be achieved without generating unintended consequences. For these two reasons, we propose that the following four questions warrant attention from future researchers.

A first area of study concerns the variety of ecological relationships that can be expected to occur in the provision for different needs, and in different cultural contexts. For instance, in the provision of mobility we find considerable connectedness, which may be due to the variety of transport modalities that people use on trips. In the provision for food, 
interactions between business models might occur less often, or have a different nature (i.e. more competitive), or occur at a different scale. Thus, a first guiding research question is:

\section{RQ1 To what extent are interactions between business models shaped by the particular need that is provided for?}

Once an understanding is developed of the interactions between business models, it becomes possible to make a more systematic assessment of their combined impact on social relations, environmental sustainability, and labour relations. Current assessments tend to focus on individual S-BMs (e.g. Goedkoop et al., 1999; Lindahl et al., 2014), and thus neglect rebound effects, the extent of substitution of existing resources, and the impacts of associated BMs (Druckman et al., 2012). This part of the research agenda is as much a methodological question as it is one about actual impacts. The formula provided above provides a starting point, but tools need to be developed to enable sensible system demarcations and selection of indicators. Answering these questions will require the collection and analysis of data on combinations of modes of provision and their impact, rather than on individual business models and initiatives. We expect our conceptual model to aid in the efficient selection of data-sources, and guide the analysis of such data in a way that deepens our insight into the contribution of sharing to sustainable development. Thus, our second question is:

\section{RQ2 How do interactions between business models affect ecological and social sustainability of provision for human needs, and what tools can be used to assess this?}

Our conceptual framework is process-oriented (Langley et al., 2013); it identifies the mechanisms through which S-BMs can diffuse through a system of provision. The mechanisms are generic, and building on transition theory we expect that the generic route depicted in Figure 3 in concrete cases will follow typical 'pathways' depending on initial 
geographical, demographic and institutional conditions, as well as external influences (Geels $\&$ Schot, 2007). In the mobility case, we see a gradual addition of new business models, which over time might lead others to go extinct. An alternative pathway might be more disruptive and sudden, or lead to the creation of 'parallel' modes of provision. The conditions responsible for a system developing along one pathway rather than another are likely to reside in the habitat (i.e. available resources and institutional embedding).

\section{RQ3 What are typical pathways through which types of provision (such as sharing) become dominant in a system of provision, and what conditions shape these pathways?}

The 'ecology of business models' perspective presented in this paper highlights the different interactions and dependencies between existing and business models and how these sustain or break down existing (unsustainable) business practices. Recognising the work by

Schaltegger et al., (2016) and earlier work on transitions management (Kemp et al., 1998) innovations will come from niche players, incumbents, and the interplay between those. Large businesses are already experimenting with new business models for sustainability (Weissbrod and Bocken, 2017). However, often innovations start within small players experimenting with new business models in practice (Schaltegger et al., 2016). Experimentation at all levels is required and needs to be nurtured at all levels for the sharing economy to effectively develop (Kemp et al., 1998). Governments may stimulate the development of start-ups, the interactions between start-ups and large business, and incentivise innovation that breaks down existing regimes (e.g. electric replacing fossil fuels; bicycling and walking substituting driving).

To ensure sustainable value creation, experimentation with new business models will explicitly need to take into account societal and environmental impact (Weissbrod and Bocken, 2017). To facilitate this, the interplay of niches emerging from start-ups, large 
incumbent business and existing infrastructures needs to be fully understood. For instance, what activities will lead to decreased fragility of start-up initiatives and remove entrenchment of existing unsustainable practices? Lelah et al. (2011) found that when aiming for greater levels of sustainability in new business model design, a careful design of the connected infrastructure is needed. If the 'connected infrastructure' (e.g. sensors, mobile connection) is over-specified, this could negatively outweigh any environmental benefits of optimisation. Our 'ecology of business models' perspective provides business practitioners as well as policy makers with a starting point for facilitating the evolution of sustainable systems (e.g. cities, regions, business eco-systems) rather than merely optimising individual activities and losing sight of the broader ecosystem. Thus, our fourth research question is:

\section{RQ4 How can experimentation with sharing business models be facilitated in a way that contributes to (environmental) sustainability, including the elimination of entrenched unsustainable practices?}

As these research questions indicate, the 'ecology of business models' perspective presented in this article provides a fruitful starting point for analytical understanding as well as innovation and redesign at the systems level. It also provides a way to integrate research into business model innovation and transitions management.

Given the choices we have made, there some limitations to our approach. One limitation concerns the current availability of empirical data that allows the analysis and assessment of ecologies of business models. Given the general focus on business models as changeable attributes of firms, a reorientation of researchers is required to seek understanding of larger social systems. This is slowly emerging through research on sustainable cities (which often seeks to include several systems of provision) and in the future this work could provide the necessary data to validate and further develop our framework. A second 
limitation is that the ecological metaphor invites the analysis of emergent phenomena, and thus downplays the role of actors that can influence in a more top down manner. As a result, our perspective perhaps underplays the more directive role that governmental authorities can play. A final limitation is our focus on environmental impact, at the expense of social and economic impact. A more integrated assessment of impact would be welcome, but can also be expected to provide further complications in terms of conceptual complexity and data requirements.

\section{References}

Acquier, A., Daudigeos, T., Pinkse, J., 2017. Promises and paradoxes of the sharing economy: An organizing framework. Technol. Forecast. Soc. Change 125, 1-10. https://doi.org/10.1016/j.techfore.2017.07.006

Aldrich, H., 1999. Organizations evolving. Sage.

Arthur, W.B., 1989. Competing Technologies, Increasing Returns, and Lock-In by Historical Events 99, 116-131.

Beinhocker, E.D., 2006. The origin of wealth: Evolution, complexity, and the radical remaking of economics. Harvard Business Press.

Belk, R., 2014. You are what you can access: Sharing and collaborative consumption online. J. Bus. Res. 67, 1595-1600. https://doi.org/10.1016/j.jbusres.2013.10.001

Belk, R., 2010. Sharing: Table 1. J. Consum. Res. 36, 715-734. https://doi.org/10.1086/612649

Bellos, I., Ferguson, M., Toktay, L.B., 2017. The car sharing economy: Interaction of business model choice and product line design. Manuf. Serv. Oper. Manag. 19, 185201.

Binswanger, M., 2001. Technological progress and sustainable development: what about the 
rebound effect? Ecol. Econ. 36, 119-132.

Blondel, V.D., Guillaume, J.-L., Lambiotte, R., Lefebvre, E., 2008. Fast unfolding of communities in large networks. J. Stat. Mech. theory Exp. 2008, P10008.

Bock, K., 2015. The changing nature of city tourism and its possible implications for the future of cities. Eur. J. Futur. Res. 3, 20. https://doi.org/10.1007/s40309-015-0078-5

Bocken, N.M.P., Short, S.W., Rana, P., Evans, S., 2014. A literature and practice review to develop sustainable business model archetypes. J. Clean. Prod. 65, 42-56. https://doi.org/10.1016/j.jclepro.2013.11.039

Bollier, D., Helfrich, S., 2014. The wealth of the commons: A world beyond market and state. Levellers Press.

Bolton, R., Hannon, M., 2016. Governing sustainability transitions through business model innovation: Towards a systems understanding. Res. Policy 45, 1731-1742. https://doi.org/10.1016/j.respol.2016.05.003

Boons, F., 2009. Creating ecological value: An evolutionary approach to business strategies and the natural environment, Creating Ecological Value: An Evolutionary Approach to Business Strategies and the Natural Environment.

Boons, F., Lüdeke-Freund, F., 2013. Business models for sustainable innovation: State-ofthe-art and steps towards a research agenda. J. Clean. Prod. 45. https://doi.org/10.1016/j.jclepro.2012.07.007

Boons, F., Montalvo, C., Quist, J., Wagner, M., 2013. Sustainable innovation, business models and economic performance: An overview. J. Clean. Prod. 45. https://doi.org/10.1016/j.jclepro.2012.08.013

Botsman, R., Rogers, R., 2010. What's mine is yours. rise Collab. Consum.

Boulding, K.E., 1966. The economics of the coming spaceship earth. Environ. Qual. Issues a Grow. Econ. 
Boyden, S., Millar, S., Newcombe, K., O’Neill, B., 1981. Ecology of a city and its people: The case of Hong Kong. Australian National University.

Bresnihan, P., Byrne, M., 2015. Escape into the city: Everyday practices of commoning and the production of urban space in Dublin. Antipode 47, 36-54. https://doi.org/10.1111/anti.12105

Callon, M., Law, J., 1982. On interests and their transformation: enrolment and counterenrolment. Soc. Stud. Sci. 12, 615-625.

Casadesus-Masanell, R., Zhu, F., 2013. Business model innovation and competitive imitation: The case of sponsor-based business models. Strateg. Manag. J. 34, 464-482. https://doi.org/10.1002/smj.2022

CBS, 2016. Transport en mobiliteit 2016.

Checkland, P., 1981. Systems thinking, systems practice.

Chertow, M.R., 2000. I $<$ scp $>$ NDUSTRIAL $<$ scp $>$ S $<$ scp $>$ YMBIOSIS $</$ scp $>$ : Literature and Taxonomy. Annu. Rev. Energy Environ. 25, 313-337. https://doi.org/10.1146/annurev.energy.25.1.313

Chesbrough, H., 2010. Business model innovation: Opportunities and barriers. Long Range Plann. 43, 354-363. https://doi.org/10.1016/j.lrp.2009.07.010

Cohen, B., Kietzmann, J., 2014. Ride On! Mobility Business Models for the Sharing Economy. Organ. Environ. 27, 279-296. https://doi.org/10.1177/1086026614546199

Cohen, B., Munoz, P., 2016. Sharing cities and sustainable consumption and production: Towards an integrated framework. J. Clean. Prod. 134 (Part, 87-97.

Cottee-Jones, H.E.W., Whittaker, R.J., 2012. Perspective: the keystone species concept: a critical appraisal. Front. Biogeogr. 4, 217-220. https://doi.org/10.5811/westjem.2011.5.6700

Davis, G.F., 2016. The vanishing American corporation: Navigating the hazards of a new 
economy. Berrett-Koehler Publishers.

DiMaggio, P., Powell, W.W., 1983. The iron cage revisited: Collective rationality and institutional isomorphism in organizational fields. Am. Sociol. Rev. 48, 147-160.

Druckman, A., Chitnis, M., Sorrell, S., Jackson, T., 2012. Corrigendum to "Missing carbon reductions? Exploring rebound and backfire effects in UK households" [Energy Policy 39 (2011) 3572-3581]. Energy Policy 49, 778. https://doi.org/10.1016/j.enpol.2012.06.045

Druckman, A., Jackson, T., 2009. The carbon footprint of UK households 1990-2004: A socio-economically disaggregated, quasi-multi-regional input-output model. Ecol. Econ. 68, 2066-2077. https://doi.org/10.1016/j.ecolecon.2009.01.013

Engeström, Y., Sannino, A., Bal, A., Lotz-Sisitka, H., Pesanayi, T., Chikunda, C., Lesama, M.F., Picinatto, A.C., Querol, M.P., Lee, Y.J., 2016. Agentive learning for sustainability and equity: Communities, cooperatives and social movements as emerging foci of the learning sciences. Proc. Int. Conf. Learn. Sci. ICLS 2, 1048-1054.

Esteves, A.M., 2016. Radical Environmentalism and "Commoning”: Synergies Between Ecosystem Regeneration and Social Governance at Tamera Ecovillage, Portugal. Antipode 49, 357-376. https://doi.org/10.1111/anti.12278

Falagas, M.E., Pitsouni, E.I., Malietzis, G.A., Pappas, G., 2008. Comparison of PubMed, Scopus, web of science, and Google scholar: strengths and weaknesses. FASEB J. 22, $338-342$.

Fehske, A., Malmodin, J., Biczók, G., Fettweis, G., 2011. The Global Footprint of Mobile Communications-The Ecological and Economic Perspective. IEEE Commun. Mag. issue Green Commun. (November 2010) 55-62. https://doi.org/10.1109/MCOM.2011.5978416

Firnkorn, J., Müller, M., 2011. What will be the environmental effects of new free-floating 
car-sharing systems? The case of car2go in Ulm. Ecol. Econ. 70, 1519-1528. https://doi.org/10.1016/j.ecolecon.2011.03.014

Fishman, E., Washington, S., Haworth, N., 2013. Bike Share: A Synthesis of the Literature. Transp. Rev. 33, 148-165. https://doi.org/10.1080/01441647.2013.775612

Foss, N.J., Saebi, T., 2017. Business models and business model innovation: Between wicked and paradigmatic problems. Long Range Plann. 1-13. https://doi.org/10.1016/j.lrp.2017.07.006

Foxon, T.J., Köhler, J., Michie, J., Oughton, C., 2013. Towards a new complexity economics for sustainability. Cambridge J. Econ. 37, 187-208. https://doi.org/10.1093/cje/bes057

Frenken, K., 2017. Political economies and environmental futures for the sharing economy. Philos. Trans. R. Soc. A Math. Eng. Sci. 375, 20160367. https://doi.org/10.1098/rsta.2016.0367

Gansky, L., 2010. The Mesh. Penguin Publishers.

Geels, F.W., 2004. From sectoral systems of innovation to socio-technical systems: Insights about dynamics and change from sociology and institutional theory. Res. Policy 33, 897-920. https://doi.org/10.1016/j.respol.2004.01.015

Geels, F.W., 2002. Technological transitions as evolutionary reconfiguration processes: a multi-level perspective and a case-study. Res. Policy 31, 1257-1274. https://doi.org/10.1016/S0048-7333(02)00062-8

Geels, F.W., Schot, J., 2007. Typology of sociotechnical transition pathways. Res. Policy 36, 399-417. https://doi.org/10.1016/j.respol.2007.01.003

Geels, F.W., Tyfield, D., Urry, J., 2014. Regime resistance against low-carbon transitions: Introducing politics and power into the multi-level perspective. Theory, Cult. Soc. 31, $21-40$.

Geels, F.W., Verhees, B., 2011. Cultural legitimacy and framing struggles in innovation 
journeys: A cultural-performative perspective and a case study of Dutch nuclear energy (1945-1986). Technol. Forecast. Soc. Change 78, 910-930.

https://doi.org/10.1016/j.techfore.2010.12.004

Goedkoop, M., Van Haler, C., Te Riele, H., Rommers, P., 1999. Product Service-Systems, ecological and economic basics. Report for Dutch Ministries of Environment (VROM) and Economic Affairs (EZ). Retrieved November 18, 2009.

Hamari, J., 2013. Transforming homo economicus into homo ludens: A field experiment on gamification in a utilitarian peer-to-peer trading service. Electron. Commer. Res. Appl. 12, 236-245. https://doi.org/10.1016/j.elerap.2013.01.004

Hamari, J., Sjöklint, M., Ukkonen, A., 2016. The sharing economy: Why people participate in collaborative consumption. J. Assoc. Inf. Sci. Technol. 67, 2047-2059. https://doi.org/10.1002/asi

Hanley, M., Henning, J., Valsan, A., Nassif, A., 2013. Eight mega trends shaping the global light vehicle industry - Executive summary. Ernst \& Young 1-2.

Hardin, G., 1968. The Tragedy of the Commons'(1968) 162. Science (80-. ). 1243.

Hawley, A.H., 1986. Human ecology: A theoretical essay. University of Chicago Press.

Hertwich, E.G., 2005. Consumption and the rebound effect - An industrial ecology perspective. J. Ind. Ecol. 9, 85-98. https://doi.org/10.1162/1088198054084635

Hodson, M., Geels, F., Mcmeekin, A., 2015. Country report 6 : The UK mobility system.

Hracs, B.J., 2012. A Creative Industry in Transition: The Rise of Digitally Driven Independent Music Production. Growth Change 43, 442-461. https://doi.org/10.1111/j.1468-2257.2012.00593.x

Iansiti, M., Levien, R., 2004. Strategy as Ecology. Harv. Bus. Rev. 82. https://doi.org/10.1108/eb025570

ISO, 2006. ISO 14044: Environmental Management, Life Cycle Assessment, Requirements 
and Guidelines. ISO.

Kemp, R., Schot, J., Hoogma, R., 1998. Regime shifts to sustainability through processes of niche formation: The approach of strategic niche management. Technol. Anal. Strateg. Manag. 10, 175-195. https://doi.org/10.1080/09537329808524310

Kennedy, C., Cuddihy, J., Engel-Yan, J., 2007. The changing metabolism of cities. J. Ind. Ecol. 11, 43-59.

Kennedy, J., 2015. Conceptual boundaries of sharing. Information, Commun. Soc. 4462, 114. https://doi.org/10.1080/1369118X.2015.1046894

Koopman, C., Mitchell, M., Thierer, A., 2015. The Sharing Economy and Consumer Protection Regulation: The Case for Policy Change. J. Business, Entrep. Law 8, 530545. https://doi.org/10.2139/ssrn.2535345

Lan, J., Ma, Y., Zhu, D., Mangalagiu, D., Thornton, T.F., 2017. Enabling value co-creation in the sharing economy: The case of mobike. Sustain. 9. https://doi.org/10.3390/su9091504

Lelah, A., Mathieux, F., Brissaud, D., 2011. Contributions to eco-design of machine-tomachine product service systems: the example of waste glass collection. J. Clean. Prod. $19,1033-1044$.

Levin, S., 2007. Fragile dominion. Basic Books.

Lifset, R., Boons, F., 2012. Industrial Ecology: Business Management in a Material World, The Oxford Handbook of Business and the Natural Environment. https://doi.org/10.1093/oxfordhb/9780199584451.003.0017

Lindahl, M., Sundin, E., Sakao, T., 2014. Environmental and economic benefits of Integrated Product Service Offerings quantified with real business cases. J. Clean. Prod. 64, 288296.

Liwarska-Bizukojc, E., Bizukojc, M., Marcinkowski, A., Doniec, A., 2009. The conceptual model of an eco-industrial park based upon ecological relationships. J. Clean. Prod. 17, 
$732-741$.

Mair, J., Reischauer, G., 2016. Capturing the dynamics of the sharing economy: Institutional research on the plural forms and practices of sharing economy organizations. Technol. Forecast. Soc. Change 125, 11-20. https://doi.org/10.1016/j.techfore.2017.05.023 Martin, C.J., 2016. The sharing economy: A pathway to sustainability or a nightmarish form of neoliberal capitalism? Ecol. Econ. 121, 149-159. https://doi.org/10.1016/j.ecolecon.2015.11.027

McMeekin, a., Southerton, D., 2007. Innovation and final consumption: social practices, instituted modes of provision and intermediation. ... Res. Innov. ... 44, 1-37.

Millard-Ball, A., Murray, G., Schure, J. Ter, Fox, C., Burkhardt, J., 2005. Car-Sharing: Where and How it Succeeds, Transportation Research Board. https://doi.org/10.17226/13559

Mills, L.S., Soule, M.E., Doak, D.F., 1993. The Keystone-Species Concept in Ecology and Conservation. Bioscience. https://doi.org/10.2307/1312122

MÖHLMANN, M., 2015. Collaborative consumption: determinants of satisfaction and the likelihood of using a sharing economy option again. J. Consum. Behav. 14, 193-207. https://doi.org/10.1002/cb

Moore, J., 1996. The death of competition.

Nijland, H., van Meerkerk, J., 2017. Mobility and environmental impacts of car sharing in the Netherlands. Environ. Innov. Soc. Transitions 1-8. https://doi.org/10.1016/j.eist.2017.02.001

Odum, E., Barrett, G.W., 2004. Fundamentals of ecology.

Ostrom, E., 1990. Governing the commons. Cambridge university press, Cambridge.

Paiano, A., Lagioia, G., Cataldo, A., 2013. A critical analysis of the sustainability of mobile phone use. Resour. Conserv. Recycl. 73, 162-171. 
https://doi.org/10.1016/j.resconrec.2013.02.008

Park, R.E., 1911. Human communities: The city and human ecology. EJ Brill.

Parkes, S.D., Marsden, G., Shaheen, S.A., Cohen, A.P., 2013. Understanding the diffusion of public bikesharing systems: Evidence from Europe and North America. J. Transp.

Geogr. 31, 94-103. https://doi.org/10.1016/j.jtrangeo.2013.06.003

Pickett, S.T.A., Meiners, S., Cadenasso, M., 2011. Domain and propositions of succession theory, in: The Theory of Ecology. pp. 185-216.

Polanyi, K., 1950. The Great Transformation.

Popielarz, P.A., Neal, Z.P., 2007. The Niche as a Theoretical Tool. Annu. Rev. Sociol. 33, 65-84. https://doi.org/10.1146/annurev.soc.32.061604.123118

Poteete, A.R., Ostrom, E., 2004. Heterogeneity, group size and collective action: The role of institutions in forest management. Dev. Change 35, 435-461. https://doi.org/10.1111/j.1467-7660.2004.00360.x

Price, J.A., 1975. Sharing: The integration of intimate economies. Anthropologica 17, 3. https://doi.org/10.2307/25604933

Rauch, D.E., Schleicher, D., 2015. Like Uber, but for local governmental policy: The future of local regulation of the "Sharing Economy." Georg. Mason Univ. Law Econ. Res. Pap. Ser. 15, 1-61. https://doi.org/10.2139/ssrn.2549919

Rexfelt, O., Hiort af Ornäs, V., 2009. Consumer acceptance of product-service systems. J. Manuf. Technol. Manag. 20, 674-699. https://doi.org/10.1108/17410380910961055

Richardson, L., 2015. Performing the sharing economy. Geoforum 67, 121-129. https://doi.org/10.1016/j.geoforum.2015.11.004

Roome, N., Louche, C., 2016. Journeying toward business models for sustainability: A conceptual model found inside the black box of organisational transformation. Organ. Environ. 29, 11-35. https://doi.org/10.1177/1086026615595084 
Ryan, A., 2013. The transformative capacity of the commons and commoning. Irish J. Sociol. 21, 90-102. https://doi.org/10.7227/IJS.21.2.7

Rysman, M., 2009. The Economics of Two-Sided Markets 23, 125-143.

Sarasini, S., Linder, M., 2017. Integrating a business model perspective into transition theory: The example of new mobility services. Environ. Innov. Soc. Transitions 0-1. https://doi.org/10.1016/j.eist.2017.09.004

Schaltegger, S., Hansen, E.G., Lüdeke-Freund, F., 2016. Business Models for Sustainability: Origins, Present Research, and Future Avenues. Organ. Environ. 29, 3-10. https://doi.org/10.1177/1086026615599806

Schaltegger, S., Lüdeke-Freund, F., Hansen, E.G., 2016. Business Models for Sustainability: A Co-Evolutionary Analysis of Sustainable Entrepreneurship, Innovation, and Transformation. Organ. Environ. 29, 1086026616633272-. https://doi.org/10.1177/1086026616633272

Schor, J., 2014. Debating the sharing economy, great transition initiative.

Schor, J.B., Fitzmaurice, C., 2015. Collaborating and connecting: the emergence of the sharing economy(Chapter 26). Handb. Res. Sustain. Consum. 410-425. https://doi.org/10.4337/9781783471270

Shaheen, S., Cohen, A., Chung, M., 2009. North American carsharing: a ten-year retrospective. Transp. Res. Rec. J. Transp. Res. Board 2110, 35-44.

Smith, A., 2016. Alternative technology niches and sustainable development: 12 years on. Innov. Manag. Policy Pract. 18. https://doi.org/10.1080/14479338.2016.1241153

Smith, A., Stirling, A., Berkhout, F., 2005. The governance of sustainable socio-technical transitions. Res. Policy 34, 1491-1510. https://doi.org/10.1016/j.respol.2005.07.005

Sosna, M., Trevinyo-Rodriguez, R.N., Velamuri, S.R., 2010. Business model innovation through trial-and-error learning: The naturhouse case. Long Range Plann. 43, 383-407. 
https://doi.org/10.1016/j.lrp.2010.02.003

Southerton, D., 2014. Provisioning. Blackwell's Encycl. Sociol.

Stubbs, W., Cocklin, C., 2008. Conceptualizing a "Sustainability Business Model." Organ. Environ. 21, 103-127. https://doi.org/10.1177/1086026608318042

Sundararajan, A., 2016. The sharing economy: The end of employment and the rise of crowdbased capitalism. Mit Press.

Teece, D.J., 2010. Business models, business strategy and innovation. Long Range Plann. 43, 172-194. https://doi.org/10.1016/j.lrp.2009.07.003

Teece, D.J., 2007. Performance and microfoundations of (sustainable) enterprise peformance explicating dynamic capabilities. Strateg. Manag. J. 28, 1319-1350. https://doi.org/10.1002/smj.64()Received

Timmerman, P., White, R., 1997. Megahydropoiis: coastal cities in the context of global environmental change. Glob. Environ. Chang. 7, 205-234.

https://doi.org/10.1016/S0959-3780(97)00009-5

Tsujimoto, M., Kajikawa, Y., Tomita, J., Matsumoto, Y., 2015. Designing the coherent ecosystem: Review of the ecosystem concept in strategic management. Portl. Int. Conf. Manag. Eng. Technol. 2015-Septe, 53-63. https://doi.org/10.1109/PICMET.2015.7273192

Tukker, A., 2015. Product services for a resource-efficient and circular economy - A review. J. Clean. Prod. 97, 76-91. https://doi.org/10.1016/j.jclepro.2013.11.049

Turnheim, B., Håkansson, I., 2015. Forward-looking analysis of transition pathways with socio-technical scenarios: the Dutch mobility system.

Urry, J., 2004. The "System” of Automobility. Theory, Cult. Soc. 21, 25-39. https://doi.org/10.1177/0263276404046059

Van Eck, N.J., Waltman, L., 2010. Software survey: VOSviewer, a computer program for 
bibliometric mapping. Scientometrics 84, 523-538.

Verbong, G., Geels, F.W., Raven, R.P.J.M., 2008. Multi-niche analysis of dynamics and policies in Dutch renewable energy innovation journeys (1970-2006): hype-cycles, closed networks and technology-focused learning. Technol. Anal. Strateg. Manag. 20, 555-573. https://doi.org/10.1080/09537320802292719

Vieira, E.S., Gomes, J.A.N.F., 2009. A comparison of Scopus and Web of science for a typical university. Scientometrics 81, 587-600. https://doi.org/10.1007/s11192-0092178-0

Villarroel Walker, R., Beck, M.B., Hall, J.W., Dawson, R.J., Heidrich, O., 2014. The energywater-food nexus: Strategic analysis of technologies for transforming the urban metabolism. J. Environ. Manage. 141, 104-115. https://doi.org/10.1016/j.jenvman.2014.01.054

Weissbrod, I., Bocken, N.M.P., 2017. Developing sustainable business experimentation capability - A case study. J. Clean. Prod. 142, 2663-2676. https://doi.org/10.1016/j.jclepro.2016.11.009

Wilhelms, M.P., Henkel, S., Falk, T., 2016. To earn is not enough: A means-end analysis to uncover peer-providers' participation motives in peer-to-peer carsharing. Technol. Forecast. Soc. Change 125, 38-47. https://doi.org/10.1016/j.techfore.2017.03.030

Wittel, A., 2011. Qualities of Sharing and their Transformations in the Digital Age. Int. Rev. Inf. Ethics 15, 3-8.

Yates, L., 2016. Sharing, households and sustainable consumption. J. Consum. Cult. 1469540516668229. https://doi.org/10.1177/1469540516668229

Yoon, B., Kim, S., Rhee, J., 2012. An evaluation method for designing a new product-service system. Expert Syst. Appl. 39, 3100-3108. https://doi.org/10.1016/j.eswa.2011.08.173 


\footnotetext{
' For convenience, we will use the term 'business model' to denote sharing initiatives, regardless of whether they are profit-oriented or not. See the discussion below on the terminology of 'modes of provision'.

ii It should be noted that a one synonym for sharing economy is peer-to-peer economic activity (Schor 2014). This downplays the role played by the actors that create the platform, who may also be the ones that reap significant economic benefit from it.

iii The choice for mobility is based on the availability of detailed empirical work on both the existing system (Geels et al., 2011), and recently emerging sharing business models. More specifically, we draw on empirical work from the European Environmental Agency (European Environmental Agency, 2016) as well as the Pathways project, which provides detailed material on the UK and The Netherlands mobility system and emerging sharing business models (Geels, Mcmeekin, \& Hodson, 2015; Hodson et al., 2015; Turnheim et al., 2015)This work provides a rare instance of comparative data on existing and emerging modes of provision in mobility systems, which we used through secondary data analysis (Heaton, 2013). Unless otherwise indicated, data on the UK and Netherlands system draw on these reports. In addition, we draw on academic research that is often based on empirical material from other countries.

iv https://www.gov.uk/government/statistical-data-sets/nts09-vehicle-mileage-and-occupancy\#table-nts0906, [data downloaded 19-3-2017]

${ }^{\vee}$ http://www.businessofapps.com/uber-usage-statistics-and-revenue/ [accessed 16-3-2017]

vi http://www.forbes.com/sites/markrogowsky/2013/12/28/kandi-crush-an-electric-car-vending-machine-

from-china-could-upend-the-auto-industry/ (2013)

vii http://www.autorentalnews.com/channel/rental-operations/article/story/2015/03/carsharing-state-of-themarket-and-growth-potential.aspx [accessed 16-3-2017]

viii http://www.vdi-nachrichten.com/Technik-Gesellschaft/Die-Maer-Nachhaltigkeit;

http://fortune.com/2016/11/29/uber-eu-court/ [both accessed 16-3-2017]

${ }^{i x}$ http://nordic.businessinsider.com/the-companies-most-likely-to-get-driverless-cars-on-the-road-first-20174 ? $r=U S \& I R=T$

${ }^{\times}$https://www.tesla.com/supercharger [accessed 10-4-2017]
} 